Brit. J. industr. Med., 1958, 15, 243.

\title{
CHRONIC CHLOROFORM INTOXICATION
}

BY

\author{
P. J. R. CHALLEN, D. E. HICKISH, and JOAN BEDFORD
}

From the Slough Industrial Health Service and the Medical Research Council, Radiobiological Research Unit, Harwell

(RECEIVED FOR PUBLICATION MARCH 20, 1958)

Chloroform was discovered in 1831 by a French chemist, Soubeiran, and independently by the American, Samuel Guthrie of Sachett's Harbour, in the State of New York (Duncum, 1947). Soubeiran obtained impure chloroform, which he provisionally called " bichloric ether", by distilling a mixture of chloride of lime and alcohol. Liebig, in the following year, obtained a purer chloroform, which he named " liquid chloride of carbon", by a similar process. It was not until 1834 that Dumas succeeded in obtaining and correctly analysing pure chloroform and it was he who first gave it that name.

According to David Waldie, chemist to the Apothecaries' Company of Liverpool, "chloric ether " was first introduced into British practice as a medical agent in Liverpool in 1838 or 1839 , where a prescription containing " chloric ether" as one of the ingredients was brought to the Apothecaries Hall. On looking into the matter-for the substance was unknown-he found the formula for its preparation in the United States Dispensatory.

James Young Simpson first saw ether-inhalation anaesthesia successfully practised in January, 1847, and at that time he was impressed with the idea that other therapeutic agents would be found which could be introduced into the system with equal rapidity through the channel of pulmonary absorption. In October, 1847, David Waldie directed his attention to chloroform. By November, 1847, Simpson could report that he had used chloroform as an anaesthetic in tooth-drawing, opening abscesses, for annulling the pain of dysmenorrhoea and of neuralgia, in obstetric practice, and through the kindness of Professor Miller and Mr. Duncan had tried its effects in three cases of surgical operation at the Royal Infirmary of Edinburgh.

The first death under chloroform anaesthesia occurred near Newcastle on January 28,1848 , in a healthy girl of 15 who was having a toe-nail removed. At necropsy death was ascribed to congestion of the lungs, but Snow thought that an overdose had been given resulting in paralysis of the respiratory mus- cles. Since this time the popularity of chloroform as an anaesthetic has waxed and waned and has often been the subject of violent controversy.

Physical Properties and Industrial Applications

Chloroform, $\mathrm{CHCl}_{3}$, is a colourless, clear, very volatile sweet-tasting liquid with a characteristic odour; it has a specific gravity of 1.50 and boils at $61 \cdot 2^{\circ} \mathrm{C}$. The liquid is not inflammable but the vapour is capable of burning.

Commercially it is not a popular solvent but is so used in the lacquer industry, in artificial silk manufacture, in the plastics industries, as a constituent of floor polishes, for the sterilization of catgut (in which case it is usually mixed with methanol), and, to some extent as a cleaning fluid.

\section{Toxicity}

Chloroform vapour is absorbed and excreted through the respiratory tract but a little is decomposed in the organism and is present in the urine as chloride. The vapour exerts a local stimulant and irritant effect on the skin, conjunctiva, and mucous membranes of the respiratory and alimentary passages. Like other members of the group of chlorinated hydrocarbons, chloroform exerts a narcotic effect and damages the liver and kidneys, but in this respect it is considered to be of a lower order of toxicity than carbon tetrachloride (Browning, 1953). Intoxication from exposure to chlorinated hydrocarbons occurs in acute and chronic forms, and there is little doubt that certain constitutional factors render some persons more susceptible than others (Hamilton and Hardy, 1949).

The casualties during and after chloroform anaesthesia have been well described. Death during anaesthesia is the result of cardiac and respiratory failure, whereas damage to the liver and kidneys characterizes delayed poisoning. There is almost a complete lack of information on acute and chronic intoxication from exposure to chloroform in industry.

Moore (1955), working in an industry which 
manufactures chloroform, stated that he knew of one employee who developed acute narcotic symptoms and this resulted from carelessness during maintenance operations. He added that there is little danger from the small concentrations of chloroform that occur in the atmosphere when the plant is working properly. Browning $(1953,1955)$ quotes two instances of poisoning from exposure to low concentrations of chloroform. In the first case several women were employed in sterilizing catgut using chloroform in a workshop where the ventilation was inadequate, consisting of two small roof windows and a fan which had not been used for over a year. Only one of the girls made any complaint of illhealth; she said she felt dazed and drowsy. In the second case a chemist's apprentice, engaged in decanting chloroform, complained of vertigo, headache, and an inability to stand upright. Lehmann and Flury (1943) write : "Industrial poisonings, in contrast to the numerous medical experiences with chloroform, are very rare." They add that working with chloroform leads to an increased flow of saliva and tears and that dizziness, stupor, and disturbances of equilibrium are observed, but they do not refer to any specific instances of intoxication.

Heilbrunn, Liebert, and Szanto (1945) describe the clinical effects of chloroform addiction in 29 authentic cases which they were able to collect from the literature since 1830 . The chloroform was usually consumed by inhalation, but occasionally supplemented by oral administration, in doses ranging from a few drops to $1,000 \mathrm{ml}$. in 24 hours, and over a period of time of from three to 40 years. The effects described varied from negligible to "wrecking of the physical and mental energy of the patient". Some common symptoms and clinical signs were irritability, anxiety, periodic depression, delusions, hallucinations, paraesthesiae, hand tremors, and emaciation. The chronic effects of addiction to chloroform bear some resemblance to those of chronic alcoholism.

In bygone years anaesthetists must have had many hours of exposure to chloroform in their working atmosphere. Dr. H. G. Epstein, of the Nuffield Department of Anaesthetics, Oxford, however, informed us (1955) that he could not trace any relevant article in the literature on anaesthetics available to him. He considered that the risk of exposure to chloroform vapour in operation theatres has always been much less than that to ether vapour, as chloroform has been given in many cases from small inhalers which must have greatly reduced the contamination of the ambient air.

\section{Description of the Processes}

The investigation to be described was the outcome of an enquiry to our Laboratories from a firm employing some 1,500 workers, of whom $75 \%$ were women. A full-time nurse is employed but there is no medical officer.

One of their products is a well-known type of medicinal lozenge, and difficulties had arisen owing to the use of chloroform as one of the main ingredients. The manufacturing process consists of two operations, mixing and cutting, which are carried out by different groups of employees in two separate workrooms. In the mixing room, the ingredients are placed in a mechanically operated mixing drum, which is kept closed during the mixing period of about 20 minutes. The moist paste is then discharged into an open metal tray, covered with a damp cloth, and removed to the cutting room. The emptying of the mixer is shown in Fig. 1. In the cutting room the mixture is loaded by hand into a hopper, from which it is extruded in sheets. These sheets are then mechanically cut into lozenge form, dusted with sugar, stored for 24 to 48 hours to harden, and subsequently packed. Both cutting and hardening take place in the same room, which is kept at a temperature of $78^{\circ} \mathrm{F}$. or more, and in which the windows are kept shut. A general view of the room is shown in Fig. 2.

In 1947 mechanization of the cutting operation increased the capacity of the plant from $3 \mathrm{cwt}$. to $17 \mathrm{cwt}$. per day, although the average seasonal output was only $9 \mathrm{cwt}$. per day. In 1950 the operators began to complain of the vapours which were given off from the paste during the cutting and hardening processes, and it was alleged that unpleasant symptoms were being experienced. These were largely subjective in nature, and were not regarded seriously at first, particularly as it was suspected that a temporary assistant in this department, who had had some previous medical training, might have been partly responsible for the suggestion that the " fumes" could cause symptoms. However, the complaints continued, and a system of part-time working was instituted and some improved ventilation provided. These measures, however, did not solve the problem and eventually the whole group of operators refused to continue working on this particular process. In 1954 a new team of operators was engaged, and in 1955 a system of exhaust ventilation was installed. Since this time work has continued without interruption, but the management was anxious to confirm the effectiveness of the exhaust ventilation system. We were therefore asked to assess the concentrations of chloroform in the air of the cutting room with the plant in operation, but we eventually carried out a much more detailed investigation than had originally been envisaged. 
FrG. 1.-Emptying of mixer.

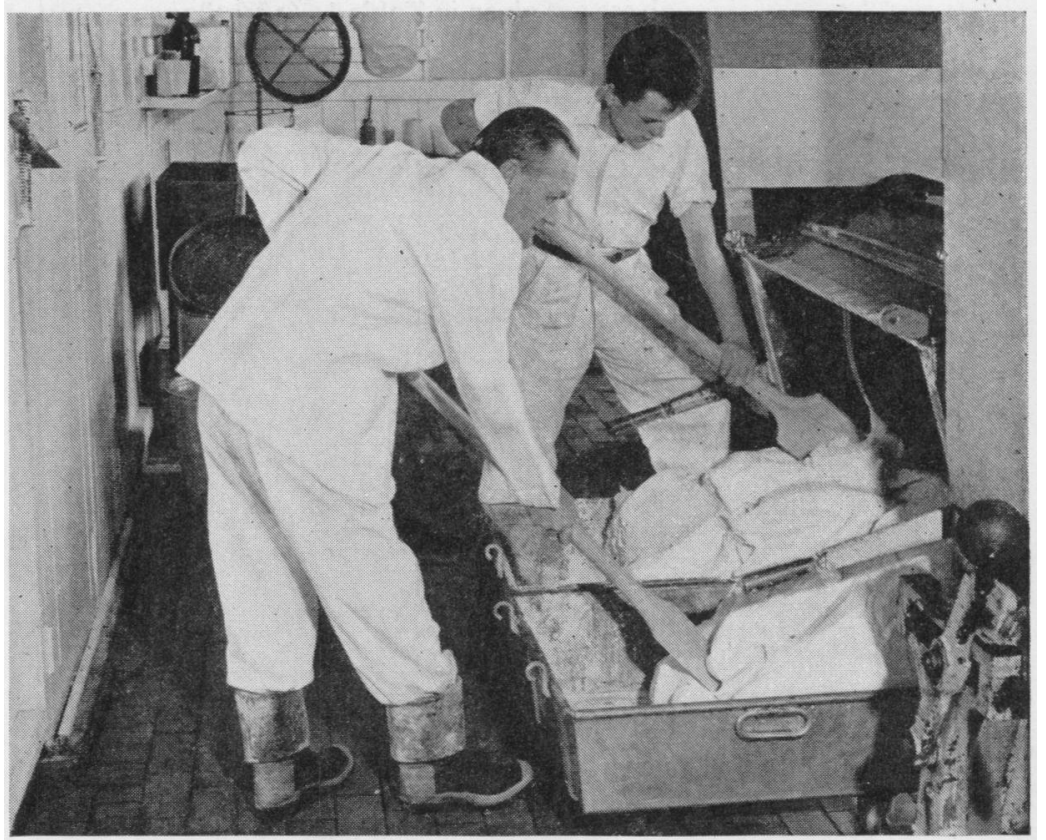

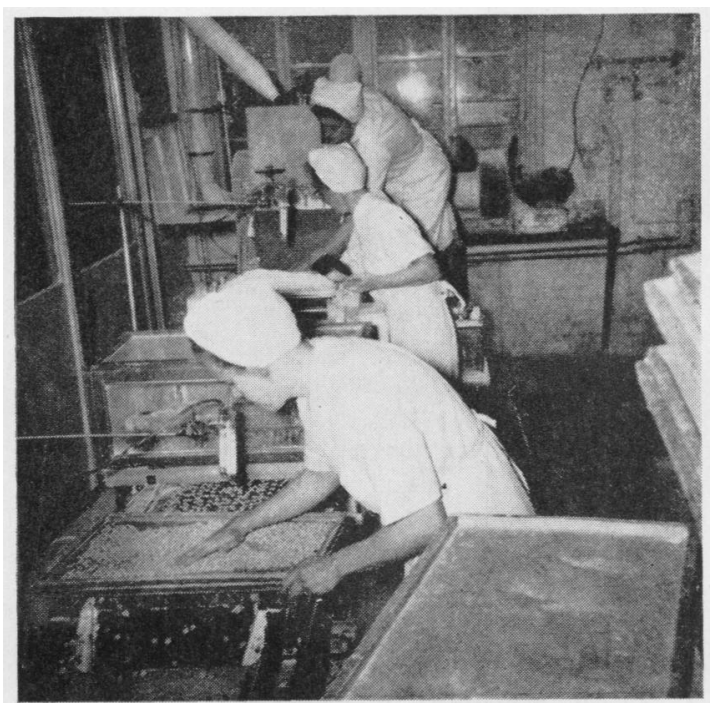

Fis. 2.-General view of cutting room.

Environmental Investigation and Results

In the first series of environmental measurements, the normal methods of production were in progress. In the mixing room a continuous air sample was taken at the breathing zone of the operator during the mixing period of 20 minutes, the sample being drawn at 1 litre per minute through two U-tubes in series, each containing dried silica gel. In addition a large " grab" sample of approximately 6 litres of air was taken at the breathing zone of the operator at the time of emptying of the mixer, when a peak concentration was expected. Air samples of 30 minutes' duration were also taken simultaneously at the breathing zones of the operators at three positions in the cutting room during two periods of production on the same day; the exhaust ventilation was then in operation, but windows were kept closed. These air samples were subsequently analysed for chloroform by a modification of the Volhard method (Elkins, 1950; Hickish, Smith, and Bedford, 1956).

We wished to know the concentrations of chloroform to which the original workers in the cutting room had been exposed, i.e., after the process had been mechanized but before the installation of exhaust ventilation, and an attempt was made to simulate the original conditions so far as was practicable. The doors and windows of the cutting room were kept closed and the exhaust ventilation was not in operation; it was considered by those who had seen the previous methods of working that a reasonable simulation was achieved in this way. There was general agreement that the concentrations occurring during the simulated operation were certainly not in excess of those previously experienced. The air samples were again taken in positions corresponding to those in the first series of measurements in the cutting room, and also in the centre of the room. 
The results of the air analyses are given in Table 1.

TABLE 1

CONCENTRATIONS OF CHLOROFORM IN AIR OF MIXING AND CUTTING ROOMS OF A CONFECTIONERY FACTORY

\begin{tabular}{|c|c|c|c|}
\hline \multirow{2}{*}{ Operation } & \multicolumn{3}{|c|}{$\begin{array}{c}\text { Chloroform Concentration } \\
\text { (p.p.m.)* }\end{array}$} \\
\hline & Period 1 & Period 2 & Period 3 \\
\hline $\begin{array}{l}\text { Mixing room during normal } \\
\text { operation } \\
\text { Continuous sample during mix- } \\
\text { ing period } \\
\text { Grab sample during emptying } \\
\text { period } \\
\text { Cutting room during normal } \\
\text { operating conditions } \\
\text { Feeding operation } \\
\text { Dusting operation } \\
\text { Removing trays } \\
\text { Cutting room during simulation of } \\
\text { original conditions } \\
\text { Feeding operation } \\
\text { Dusting operation } \\
\text { Removing trays } \\
\text { General atmosphere at centre of } \\
\text { room }\end{array}$ & $\begin{array}{r}71 \\
35 \\
23 \\
\\
219 \\
110 \\
77 \\
82\end{array}$ & $\begin{array}{r}57 \\
31 \\
29 \\
\\
237 \\
158 \\
92 \\
98\end{array}$ & $\begin{array}{l}161 \\
155 \\
-\end{array}$ \\
\hline
\end{tabular}

-The present value of the maximum allowable concentration (M.A.C.) for chloroform has been set by the American Conference of (M.A.C.) for chloroform has been set by the American Conference of Governmental Industrial Hygienists a

The concentration of 1,163 p.p.m. occurs only for a period of one and a half to two minutes during the emptying of the mixer, and contributes largely to the average concentration of 128 p.p.m. Elimination of this peak, e.g., by the application of exhaust ventilation during emptying, would reduce the average exposure during the whole mixing operation to the order of between 10 and 40 p.p.m. The mixing operation is carried out not more than four times a day and thus the total time occupied on this operation is about two hours a day.

\section{Clinical Investigation and Results}

The employees who refused to continue working in the lozenge department are hereafter termed "long-service operators" and those employees who replaced them, "short-service operators". Twentytwo women (eight long-service operators, nine shortservice operators, five controls) were interviewed and given a comprehensive medical examination; in addition four employees (two female and one male long-service operators, and one female short-service operator) were interviewed but not examined. The interviews were carried out some months before the medical examinations, as there was considerable resistance to examination from the long-service operators, but eventually all but three agreed to cooperate. In the interim period a short-service operator who had been interviewed left the firm. The male long-service operator was engaged on the mixer. Eight female employees matched for age and length of employment in the firm with the long-service operators were selected as controls from other departments, but due to various reasons only five of these were available for interview and medical examination. The age distribution of the employees examined and their length of exposure to chloroform are given in Table 2.

TABLE 2

AGE AND LENGTH OF EXPOSURE TO CHLOROFORM OF LONG-SER VICE ANDSHORT-SER VICE FEMALE OPERATORS AND CONTROLS

\begin{tabular}{|c|c|c|c|c|c|}
\hline \multirow{2}{*}{ Group } & \multirow{2}{*}{ Number } & \multicolumn{2}{|c|}{ Age (years) } & \multicolumn{2}{|c|}{ Length of Exposure } \\
\hline & & Range & Mean & Range & Mean \\
\hline Long-service & 8 & 40 to 60 & 50.5 & $3-10$ & $5 \cdot 4^{*}$ \\
\hline Short-service & 9 & 34 to 51 & $42 \cdot 9$ & months & $15 t$ \\
\hline Controls & 5 & 47 to 58 & $51 \cdot 4$ & - & - \\
\hline
\end{tabular}

*Four subjects worked full time, and four worked half time.

tOne subject worked full time, and eight worked half time.

Because the long-service operators had been exposed to chloroform for many years the possibility that they might have sustained liver damage had to be considered. The thymol turbidity, serum bilirubin, and urine urobilinogen tests were selected from the usual battery of liver function tests and performed on the 22 employees previously examined. Under different circumstances we would have carried out an excretion test; however, liver function tests, even if normal, do not exclude minor liver damage and the final answer can only be given by liver biopsy. The latter test is certainly not one which would be welcomed in a factory survey.

\section{Symptomatology}

Long-service Operators.-(This group includes the three employees not examined.)

All of these employees except one were subject to the symptoms described below, in greater or lesser degree, when they were working in the lozenge department. For purposes of easy description, the symptoms are classified under the following headings:

General.-Lassitude at the end of the day and a desire to sleep: some employees reported that when they arrived home they would fall asleep in a chair, and all the employees stated that at times they were unable to concentrate on household duties.

Alimentary.-Flatulence, a " bubbling feeling" in the abdomen, a "tight feeling in the chest", a feeling as of a " ball in the upper part of the stomach", a feeling that "the stomach was distended ", nausea, loss of appetite, water brash, dry mouth, thirst, a tendency to be drinking all the time.

Urinary.-Frequency of micturition and scalding micturition.

Mental.-A feeling of being dazed, lack of con- 
centration, "slowness in grasping things", " slow witted ", depression, and irritability. The supervisor reported that on occasions her employees " got hysterical and had a feeling of wanting to giggle all the time".

All the symptoms described above could be present at work but were usually worse in the evening at home and often persisted to some extent during the weekend. One of the long-service operators did not complain of any symptoms; she was an epileptic and had been on sedative therapy for many years. No employee gave a history which suggested a previous attack of jaundice. An interesting observation made by all these employees was that since leaving employment in the lozenge department, even a short exposure to the smell of " chlorodyne" (the name given to the odour by the employees) produced nausea and a " feeling of the stomach turning over". During the course of one of our many discussions with management the statement was made to us that occasionally some of these employees had been noticed staggering about at work.

Short-service Operators.-All but two of these employees complained of symptoms. Five reported a dryness of the mouth and throat at work, two were subject to lassitude in the evening, and the operator handling the feeder stated that she was subject to attacks of flatulence and lassitude during her working hours. Two other operators had been as severely affected as the long-service operators. One was not examined because, as mentioned earlier, she left the firm; the other gave a long and complicated history of neurotic illness, so that it was difficult, in her case, to assess the importance of environmental factors.

Controls.-None of these employees complained of symptoms similar to those which have been described above.

The findings on medical examination are summarized in Table 3; no organic lesion, for instance, enlarged liver, was discovered which could be attributed to exposure to chloroform. The results and analysis of the liver function tests are shown in Tables 4 and 5.

The only difference of statistical significance $(P=0.05)$ is that between the means of thymol turbidity for the long-service and short-service groups.

TABLE 3

PHYSICAL DEFECTS DISCOVERED AT MEDICAL EXAMINATION

\begin{tabular}{|c|c|c|c|c|c|}
\hline \multicolumn{2}{|c|}{$\begin{array}{l}\text { Long-service } \\
\text { Operators }\end{array}$} & \multicolumn{2}{|c|}{$\begin{array}{c}\text { Short-service } \\
\text { Operators }\end{array}$} & \multicolumn{2}{|r|}{ Controls } \\
\hline $\begin{array}{l}\text { Case } \\
\text { No. }\end{array}$ & & $\begin{array}{l}\text { Case } \\
\text { No. }\end{array}$ & & $\begin{array}{l}\text { Case } \\
\text { No. }\end{array}$ & \\
\hline $\begin{array}{l}1 \\
2 \\
3 \\
4 \\
5 \\
6 \\
7 \\
8\end{array}$ & $\begin{array}{l}\text { Epilepsy } \\
\text { Urticarial rash } \\
\text { B.P. 180/100 } \\
\text { Age 46 } \\
\text { Nil } \\
\text { Nil } \\
\text { Nil } \\
\text { Nil } \\
\text { Nil }\end{array}$ & $\begin{array}{l}1 \\
2 \\
3 \\
4 \\
\\
5 \\
6 \\
7 \\
\\
8 \\
9\end{array}$ & $\begin{array}{l}\text { Chronic otitis } \\
\text { media (L.) } \\
\text { Thyroid adeno- } \\
\text { ma (asympto- } \\
\text { matic) } \\
\text { Nil } \\
\text { Hypertension } \\
\text { with symptoms } \\
\text { (B.P. 250/140) } \\
\text { Age 45 } \\
\text { Nil } \\
\text { Nil } \\
\text { Osteoarthritis } \\
\text { of knee joints } \\
\text { and cervical } \\
\text { spine } \\
\text { Nil } \\
\text { Nil }\end{array}$ & $\begin{array}{l}1 \\
2 \\
3 \\
\\
4 \\
5\end{array}$ & $\begin{array}{l}\text { Nil } \\
\text { Nil } \\
\text { Thyroid adeno- } \\
\text { ma (asympto- } \\
\text { matic) } \\
\text { Migraine } \\
\text { Chronic bron- } \\
\text { chitis, peptic } \\
\text { ulcer. B.P. } \\
180 / 110 \\
\text { Age } 58\end{array}$ \\
\hline
\end{tabular}

TABLE 4

RESULTS OF LIVER FUNCTION TESTS

\begin{tabular}{|c|c|c|c|c|c|c|c|c|}
\hline \multirow[b]{2}{*}{ Subject } & & \multirow[b]{2}{*}{ Age } & \multicolumn{2}{|c|}{ Urine } & \multicolumn{4}{|c|}{ Blood } \\
\hline & & & Urobilin & Urobilinogen & $\begin{array}{c}\text { Thymol Turbidity } \\
\text { (Normal Value } \\
0-5 \text { units) }\end{array}$ & $\begin{array}{c}\text { Thymol } \\
\text { Flocculation } \\
(0-1)\end{array}$ & $\begin{array}{c}\text { Van den Bergh } \\
\text { (Direct) }\end{array}$ & $\begin{array}{c}\text { Serum Bilirubin } \\
\text { (Normal Value } \\
0.1-0.8 \mathrm{mg} . / 100 \mathrm{ml} .)\end{array}$ \\
\hline Long-service operators & $\begin{array}{l}1 \\
2 \\
3 \\
4 \\
5 \\
6 \\
7 \\
8 \\
\end{array}$ & $\begin{array}{l}60 \\
57 \\
53 \\
40 \\
48 \\
46 \\
48 \\
52 \\
\end{array}$ & $\begin{array}{c}\text { Negative } \\
\text { " } \\
\text { " } \\
\text { ", } \\
\text { ", }\end{array}$ & $\begin{array}{c}\text { Negative } \\
\text { " } \\
\text { Trace } \\
\text { Negative } \\
\text { " } \\
\text { " } \\
\end{array}$ & $\begin{array}{l}1 \\
2 \\
1 \\
2 \\
1 \\
3 \\
1 \\
1\end{array}$ & $\begin{array}{l}= \\
= \\
= \\
=\end{array}$ & $\begin{array}{c}\text { Negative } \\
\text { ", } \\
\text { ", } \\
\text { ", } \\
\text { ", }\end{array}$ & $\begin{array}{l}0.3 \\
0.3 \\
0.5 \\
0.3 \\
0.2 \\
0.4 \\
0.3 \\
0.3 \\
\end{array}$ \\
\hline Short-service operators & $\begin{array}{l}1 \\
2 \\
3 \\
4 \\
5 \\
6 \\
7 \\
8 \\
9\end{array}$ & $\begin{array}{l}34 \\
35 \\
51 \\
41 \\
51 \\
45 \\
36 \\
42 \\
51\end{array}$ & $\begin{array}{c}\text { Negative } \\
\text {," } \\
\text { ", } \\
\text { ", } \\
\text { ", }\end{array}$ & $\begin{array}{l}\text { Negative } \\
\text { Trace } \\
\text { Negative } \\
\text { " } \\
\text { Trace } \\
\text { Negative }\end{array}$ & $\begin{array}{l}3 \\
2 \\
4 \\
3 \\
3 \\
3 \\
1 \\
1 \\
3 \\
4\end{array}$ & $\begin{array}{l}= \\
= \\
= \\
=\end{array}$ & $\begin{array}{c}\text { Negative } \\
\text { ", } \\
\text { ", } \\
\text { ”, } \\
\text { ", }\end{array}$ & $\begin{array}{l}0.4 \\
0.2 \\
0.2 \\
0.3 \\
0.2 \\
0.3 \\
0.2 \\
0.3 \\
0.1\end{array}$ \\
\hline Controls & $\begin{array}{l}1 \\
2 \\
3 \\
4 \\
5\end{array}$ & $\begin{array}{l}48 \\
50 \\
47 \\
54 \\
58\end{array}$ & $\begin{array}{l}\text { Negative } \\
\text { ", } \\
\text { ", }\end{array}$ & $\begin{array}{l}\text { Negative } \\
\text { ", } \\
\text { ", }\end{array}$ & $\begin{array}{l}3 \\
5 \\
1 \\
1 \\
2\end{array}$ & $\begin{array}{c}\text { Incomplete } \\
\text { = } \\
-\end{array}$ & $\begin{array}{c}\text { Negative } \\
\text { ", } \\
\text { ", }\end{array}$ & $\begin{array}{l}0.1 \\
0.3 \\
0.3 \\
0.4 \\
0.2\end{array}$ \\
\hline
\end{tabular}


TABLE 5

STATISTICAL ANALYSIS OF LIVER FUNCTION TESTS

\begin{tabular}{|c|c|c|c|c|c|}
\hline \multirow{2}{*}{ Group } & & \multicolumn{2}{|c|}{$\underset{\text { (mg./100 ml.) }}{\text { Serum }}$} & \multicolumn{2}{|c|}{$\begin{array}{c}\text { Thymol Turbidity } \\
\text { (units) }\end{array}$} \\
\hline & & Range & Mean & Range & Mean \\
\hline $\begin{array}{l}\text { Long-service (8) } \\
\text { Short-service (9) } \\
\text { Control (5) .. }\end{array}$ & $\begin{array}{l}\cdots \\
\cdots\end{array}$ & $\begin{array}{l}0 \cdot 2-0.5 \\
0 \cdot 1-0.4 \\
0 \cdot 1-0.4\end{array}$ & $\begin{array}{l}0.325 \\
0.244 \\
0 \cdot 260\end{array}$ & $\begin{array}{l}1-3 \\
1-4 \\
1-5\end{array}$ & $\begin{array}{l}1 \cdot 5 \\
2 \cdot 66 \\
2 \cdot 40\end{array}$ \\
\hline
\end{tabular}

\section{Discussion}

There is only one difference in the results of the liver function tests between long-service operators, short-service operators, and controls which is of statistical significance, and this difference is small and difficult to interpret. In view of the fact that all the results are within the normal range for these liver function tests it is concluded that there is no evidence from these tests of damage to the liver. It is unlikely that the operators from the lozenge department have suffered permanent liver damage but only liver biopsies could be the final arbiter in this judgment. Stewart and Witts (1944), discussing carbon tetrachloride, state that "to bring about permanent liver damage there must be exposure sufficient to produce an immediate toxic effect and the dose must be repeated at short intervals ", and " if each dose of carbon tetrachloride is too small to produce changes in the liver, no matter how frequently it is repeated, there will be no hepatic damage ". It is well known from animal studies that liver damage is a reversible process, that the liver has remarkable powers of repair, and that after injury it can revert to its normal state (Goldblatt and Goldblatt, 1956).

As might have been expected, there is a considerable resemblance between the clinical effects described in this paper and those recorded by Stewart and Witts (1944) in their study of chronic carbon tetrachloride intoxication. They were not able to obtain any useful figures for air concentrations of carbon tetrachloride but they state that "the characteristic symptoms of exposure to sublethal concentrations of carbon tetrachloride vapour are gastro-intestinal stress and mental hebetude", and elsewhere:

"It is therefore suggested that mental hebetude is due to the effect of carbon tetrachloride on the cerebral cortex, and the gastro-intestinal symptoms are due to stimulation of the parasympathetic or inhibition of the sympathetic centres in the hypothalamus. Both effects can be paralleled by the known actions of chloroform."

In their investigation Stewart and Witts noted that some employees acquired " such a distaste for the smell of carbon tetrachloride that they experienced attacks of vomiting in circumstances which had previously had no effect". The long-service operators in our study, with the one exception, an epileptic on sedative therapy, had all become hypersensitive to the smell of chloroform. Obviously such a phenomenon could be regarded as " psychological " or even as plain malingering, but this is not the opinion of Stewart and Witts who considered that it was necessary to look beyond the liver and kidneys for an explanation of the mechanism of chronic carbon tetrachloride intoxication. In their opinion the above symptoms " bear a strong resemblance to post-anaesthetic sickness and recall the chemical relationship between carbon tetrachloride $\left(\mathrm{CCl}_{4}\right)$, chloroform $\left(\mathrm{CHCl}_{3}\right)$, and ethyl chloride $\left(\mathrm{C}_{2} \mathrm{H}_{5} \mathrm{Cl}\right)$ "'. Cushny (1941) considers that vomiting after anaesthesia may arise as a local irritant effect and from central origin, and adds that it can occur from odour and taste " more especially in people who have been anaesthetized previously and have unpleasant associations with the odour".

Our long-service operators complained of urinary symptoms and it is difficult to explain these on the basis of a local stimulant and irritant effect on the bladder. Might a possible explanation be that of an action through the hypothalamus producing parasympathetic stimulation of the bladder?

As previously stated, the maximum allowable concentration (M.A.C.) for chloroform has been set by the American Conference of Governmental Industrial Hygienists at a level of 100 p.p.m. In discussing this value Warren Cook (1945) states:

"Since there is no published work on prolonged
exposures of animals under experimental conditions
or of humans in industrial occupations to known low
concentrations of chloroform, a value of 100 p.p.m.
is generally accepted on the basis of analogy with
carbon tetrachloride. The value as given should be
further substantiated and there should be close medical
observation of any group of workers exposed to
chloroform concentrations approximating 100 p.p.m.
As is the case with carbon tetrachloride, it would be
wise to retain exposures to less than 50 p.p.m. until
more data are available."

This view coincides with the recommendation by Imperial Chemical Industries Ltd. that the concentration of chloroform in the working atmosphere should not exceed 50 p.p.m., a value which has been set in the light of unpublished results of animal experimentation (Goldblatt, 1956). The fact that the long-service operators who had apparently been exposed to concentrations ranging from 77 to 237 p.p.m. exhibited symptoms provides confirmation that the M.A.C. should not exceed 100 p.p.m. The short-service operators who, with one exception, were working four hours daily, were exposed to concentrations of from 21 to 71 p.p.m. They also complained of symptoms, but our impression was that dryness of the mouth and throat, at least, could 
be attributable to the unsatisfactory thermal conditions. However, the employee operating the feeder who also worked four hours daily reported symptoms similar to, though less severe than, those experienced by the long-service operators. She was exposed to the highest concentrations of 56 to 71 p.p.m.

At the end of our investigations we advised the firm to make certain alterations in the exhaust ventilation system of the cutting room, to institute periodic medical supervision of the operatives at risk, and to substitute some other substance for chloroform in their product. If this last item of advice was not a feasible proposition, then the concentrations of chloroform in the working atmosphere should not be allowed to exceed 50 p.p.m. In our opinion this permissible limit offers a more reasonable factor of safety, in the light of the evidence which we accumulated.

\section{Summary}

A brief historical note on chloroform is followed by a general review of its characteristics, industrial applications, and toxicity.

An environmental and clinical investigation has been carried out in a confectionery firm where employees, engaged in the manufacture of a medicinal product, were exposed to chloroform vapour. In a group of 10 employees, believed to have been exposed to concentrations ranging from 77 to 237 p.p.m., nine complained of severe symptoms. No evidence of liver damage was found in the eight who submitted themselves to medical examination and liver function tests.

In another group of 10 employees, exposed to concentrations ranging from 22 to 71 p.p.m., eight complained of less severe symptoms. No evidence of liver damage was discovered in the nine who submitted themselves to medical examination and liver function tests.

The symptomatology is discussed in relation to that experienced by persons exposed to low concentrations of carbon tetrachloride.

The maximum allowable concentration of 100 p.p.m. recommended by the American Conference of Governmental Industrial Hygienists is considered to be too high, and the evidence from the present investigation supports the value of 50 p.p.m. suggested by Imperial Chemical Industries Ltd.

We are indebted to Professor A. W. Woodruff and Dr. D. S. Ridley of the Hospital for Tropical Diseases, 4 St. Pancras Way, London, N.W.1, for arranging facilities for clinical examinations and liver function tests; also to Professor G. P. Crowden for advice.

Our thanks are also due to the management, employees, and nursing sister of the firm concerned, without whose enthusiastic cooperation this investigation could not have been carried out.

\section{REFERENCES}

Browning, E. (1953). Rep. industr. Hlth Res. Bd (Lond.), No. 80 (rev. ed.), pp. 128 and 136

- (1955). Personal communication

Cook, W. A. (1945). Industr. Med., 14, 936.

Cushny, A. R. (1941). Pharmacology and Therapeutics, 12th ed., pp. 315-340. Churchill, London.

Duncum, Barbara M. (1947). The Development of Inhalation Anaesthesia, pp. 166, 171-173. Wellcome Historical Medical Museum (London: Geoffery Cumberlege).

Elkins, H. B. (1950). The Chemistry of Industrial Toxicology, p. 296.

Wiley, New York.

Epstein, H. G. (1955). Personal communication.

Goldblatt, M.W. (1956). Personal communication. and Goldblatt. J. (1956). In Industrial Medicine and Hygiene,
ed. Merewether, E. R. A., Vol. 3, p. 532. Butterworth, ed. Mer

Hamilton, A., and Hardy, H. L. (1949). Industrial Toxicology, 2nd ed., p. 358. Hoeber, New York.

Heilbrunn, G., Liebert, E., and Szanto, P. B. (1945). Arch. Neurol. Psychiat. (Chicago), 53, 68.

Hickish, D. E., Smith, J. H., and Bedford, Joan (1956). Brit. J. industr. Med., 13, 290.

Lehmann, K. B., and Flury, F. (1943). Toxicology and Hygiene of Industrial Solvents, pp. 138-145. Williams and Wilkins. Baltimore.

Moore, W. K. S. (1955). Personal communication.

Stewart, A., and Witts, L. J. (1944). Brit. J. industr. Med., 1, 11. 